Published in final edited form as:

Angew Chem Int Ed Engl. 2013 May 17; 52(21): . doi:10.1002/anie.201300208.

\title{
Integrated Bare Narrow Capillary-Hydrodynamic Chromatographic System for Free-Solution DNA Separation at the Single-Molecule Level**
}

\author{
Zaifang Zhu, \\ Department of Chemistry and Biochemistry, University of Oklahoma, 101 Stephenson Parkway, \\ Norman, OK 73019 (USA) \\ Huang Chen, \\ Department of Chemistry and Biochemistry, University of Oklahoma, 101 Stephenson Parkway, \\ Norman, OK 73019 (USA) \\ Dr. Wei Wang, \\ Department of Chemistry and Biochemistry, University of Oklahoma, 101 Stephenson Parkway, \\ Norman, OK 73019 (USA) \\ Aaron Morgan, \\ Department of Chemistry and Biochemistry, University of Oklahoma, 101 Stephenson Parkway, \\ Norman, OK 73019 (USA) \\ Dr. Congying Gu, \\ Department of Chemistry and Biochemistry, University of Oklahoma, 101 Stephenson Parkway, \\ Norman, OK 73019 (USA)
}

Prof. Chiyang He,

College of Chemistry and Chemical Engineering, Wuhan Textile University, Wuhan, Hubei 430073 (P.R. China)

Joann J. Lu, and

Department of Chemistry and Biochemistry, University of Oklahoma, 101 Stephenson Parkway, Norman, OK 73019 (USA)

\author{
Prof. Shaorong Liu \\ Department of Chemistry and Biochemistry, University of Oklahoma, 101 Stephenson Parkway, \\ Norman, OK 73019 (USA) \\ Chiyang He: chiyanghe@hotmail.com; Shaorong Liu: shaorong.liu@ou.edu
}

\section{Keywords}

chromatography; DNA separation; electroosmotic pump; integrated system; microfluidic chip

We report an integrated bare narrow-capillary-hydrodynamic chromatographic system (BaNC-HDC) for rapid, high-resolution, and repeatable separations of a wide size range of

\footnotetext{
** We thank Department of Energy (DE-SC0006351), National Science Foundation (CHE 1011957), and the Oklahoma Center for the Advancement of Science and Technology (AR11-003) for support.

(C) 2013 Wiley-VCH Verlag GmbH \& Co. KGaA, Weinheim

Correspondence to: Chiyang He, chiyanghe@hotmail. com; Shaorong Liu, shaorong. liu@ou.edu.

Supporting information for this article is available on the WWW under http://dx.doi.org/10.1002/anie.201300208.
} 
DNA at the single-molecule level in free solution. DNA separation is a common task in molecular biological research. Traditionally, DNA molecules are separated using slab-gel electrophoresis, ${ }^{[1]}$ including pulsed field gel electrophoresis (PFGE) ${ }^{[2]}$ To improve resolution, reduce running time, and increase throughput, capillary gel electrophoresis (CGE) and later capillary array electrophoresis (CAE) have been developed, and high resolutions have been achieved. ${ }^{[3]}$ However, both CGE and CAE require viscous polymer sieving matrices, which can be difficult to work with, especially when narrow capillaries are employed. Researchers have experimented with separating DNA in free solutions, but DNA cannot be easily resolved in these media because all DNA molecules have similar mass-tocharge ratios $(\mathrm{m} / \mathrm{z})$, and, as a result, similar electrophoretic mobilities. In 1992, Noolandi ${ }^{[4]}$ proposed an approach to solve this problem by attaching a monodisperse entity to each DNA fragment, generating varying $\mathrm{m} / z$ values for the DNA to be separated. The idea was experimentally validated in the late $1990 \mathrm{~s}^{[5]}$ and termed end-labeled free-solution electrophoresis (ELFSE). This method has proven to be effective for separating DNA fragments shorter than a few hundreds of base pairs. ${ }^{[6]}$ Other gel-free approaches for DNA separation include radial migration, ${ }^{[7]}$ liquid chromatography, ${ }^{[8]}$ entropic trapping, ${ }^{[9]}$ and DNA prism. ${ }^{[10]}$ These approaches overcome the problems brought by viscous gels and offer promising alternatives for resolving DNA, but their resolutions are not competitive compared to that of gel electrophoresis. Recently, we have developed a new technique, called BaNC-HDC, ${ }^{[11]}$ for free-solution DNA separations. When DNA molecules are transported inside a narrow capillary under pressure-driven conditions, the DNA molecules move as particles. ${ }^{[12]}$ Larger DNA fragments have greater effective diameters and cannot go as close to the capillary wall (the slow-moving region) as smaller fragments can and, therefore, they move faster. On the basis of this principle, samples of DNA fragments with a wide size range have been separated with resolutions comparable to gel electrophoresis. ${ }^{[11]}$ The minimal waste generation and low operation costs make BaNC-HDC an attractive alternative to gel-based techniques, particularly to PFGE for separating large DNA fragments. Herein, we integrate a high-pressure electroosmotic pump (EOP) and a microfabricated chip-injector with BaNC-HDC; the integrated system enables us to inject samples at low-picoliter $(\mathrm{pL})$ volumes reliably, elute analytes at hundreds of $\mathrm{pLmin}^{-1}$ flowrates or lower reproducibly, and resolve a wide size range of DNA fragments rapidly in free solution at the single-molecule level.

Figure 1A presents a schematic configuration of the integrated system. It consisted of an EOP, a chip injector, and a bare, narrow, open capillary column. A confocal laser-induced fluorescence (LIF) detector (see Supporting Information for details) was attached to the capillary for on-column detection. A six-port valve was utilized in conjunction with the chip injector to facilitate sample injection and BaNC-HDC separation. The valve could be switched between an "open" position (as the two auxiliary capillaries from positions 2 and 4 on the chip injector were connected to $\mathrm{S}$ and $\mathrm{W}$ ) and a "closed" position (as the two auxiliary capillaries were connected to blocked ports). Figures 1B-E depict an operation procedure of the system. Step 1 (see Figure 1B): the sample (S) was first aspirated into the cross section of the chip injector by applying vacuum to $\mathrm{W}$ for approximately 20 seconds, while the valve was set at the "open" position and the EOP was powered off. Step 2 (see Figure 1C): the valve was switched to the "closed" position, and the EOP was turned on; a portion of the sample in the cross section was driven into the separation capillary. The quantity of the injected sample was controlled by the flow rate of the EOP and the injection time. Step 3 (see Figure 1D): the valve was switched back to the "open" position while the EOP was on; the residue sample in the chip injector was flushed to W. Step 4 (see Figure $1 \mathrm{E})$ : while the EOP was on, the valve was switched to the "closed" position; the separation was carried out. With this operation procedure, we could routinely obtain better than $5 \%$ relative standard deviations (peak areas). More importantly, we could accurately control the injected sample volumes to as little as a few $\mathrm{pL}$. 
Figure 2A presents four chromatograms as the injected volume was increased from $1.2 \mathrm{pL}$ to $6.5 \mathrm{pL}$. The injected volumes were estimated by the product of flow rate inside the separation capillary and the injection time. The flow rate was measured by connecting a piece of $10 \mu \mathrm{m}$-i.d. capillary to the end of the separation column and monitoring the speed of the moving meniscus inside the $10 \mu \mathrm{m}$-i.d. capillary. The peak area increased linearly with injected volume (all with linear regression coefficients of greater than 0.997, see Figure S2 in the Supporting Information for details), an indication that the injected volumes were accurately and precisely controlled. Resolutions usually improved as the injected volume decreased (see Figure S3).

We also incorporated our recently developed high-pressure EOP to drive BaNC-HDC separations, which enabled us to tune the pumping pressure and elution rate precisely and conveniently. We had initially utilized an Agilent HPLC pump, but we had to use a flow splitter with high splitting ratios, because the elution rates for BaNC-HDC were normally around a few hundred $\mathrm{pLmin}^{-1}$ or less. We have developed a battery-like EOP unit; ${ }^{[13]}$ one unit may produce only a moderate pumping pressure, but we could connect a number of these units in series to create a high pumping pressure. This pump was perfectly suited for BaNC-HDC, because it could readily generate flow rates of several-hundred $\mathrm{pLmin}^{-1}$ or lower while simultaneously producing pumping pressures of several-hundred bar. Figure $2 \mathrm{~B}$ presents five chromatograms under different elution pressures. It is worth pointing out that 1) each separation consumed only pg of DNA and $\mathrm{nL}$ of eluent $\left(5 \mathrm{mM} \mathrm{NH} 4 \mathrm{Ac} / \mathrm{NH}_{4} \mathrm{OH}\right.$ at $\mathrm{pH} \mathrm{8.0,} \mathrm{nothing} \mathrm{else),} \mathrm{and} \mathrm{2)} \mathrm{generated} \mathrm{nL}$ of waste (the eluent plus the sample). As expected, the separation speed increased proportionally with the increasing pressure. Under $14 \mathrm{MPa}$, all 15 fragments in the GeneRuler 1-kb plus DNA ladder were eluted out in less than $4.5 \mathrm{~min}$. Except for the $400 \mathrm{bp}$ and $500 \mathrm{bp}$ fragments, all DNA were baseline-resolved. It should be noted that any speed gain came from some resolution loss (see Figure S4).

With this integrated system, we could test the effect of capillary column length on resolution and optimize the column length conveniently and rapidly. In general, we made a series of optical windows on a single capillary column, and ran BaNC-HDC separation using all these windows (one at a time). Figure 3 presents a set of experimental results using this approach; multiple windows were produced on a $69.4 \mathrm{~cm}$-long column at the indicated distance from the injector. At a distance of $14.7 \mathrm{~cm}$, all 15 DNA fragments were eluted out in less than 2.3 min (all peaks appeared within a time-window of less than $0.8 \mathrm{~min}$ ). Shorter distances could be tested, but the DNA molecules would not be well-resolved. Although tests may need to be carried out at a high elution pressure, a lower pressure will be required if the optimized column length is shorter.

Because of the low injection volumes, BaNC-HDC requires only a few DNA molecules for its assays. In Figure 2A, the bottom chromatogram was obtained using a sample containing $0.8 \mathrm{ng} \mu \mathrm{L}^{-1}$ of the $20 \mathrm{kbp}$ fragment (ca. $6.2 \times 10^{-11} \mathrm{M}$ ). With an injection volume of $1.2 \mathrm{pL}$, the number of molecules separated and detected by BaNC-HDC was less than 40 . To explore the limit of detection, we selected an injection volume of $2.4 \mathrm{pL}$, diluted the sample, and separated the DNA again. Figure 4 shows two of the chromatograms. We can see clearly all 15 DNA peaks in the top chromatogram, but some of the peaks were buried by the background noise in the bottom chromatogram. The peak pattern of the bottom chromatogram also seemed to have been distorted, likely because of a) the limited data acquisition rate $(20 \mathrm{~Hz})$ of the LIF, which could lead to the loss of the peak fluorescence signal, and b) the position uncertainty of the DNA molecules, which could lead to a low fluorescence signal if a DNA molecule resided away from the focal point of the LIF detector. The number of DNA molecules contributing to the peaks (from left to right) in the top chromatogram was calculated to be $9,19,27,140,47,62,93,498,233,333,1400,583$, 778,1166 , and 3110 , respectively. While it is exciting to obtain such low detection limits 
using our simple LIF detector, it should be pointed out that there were a number of fluorescent dyes in each DNA fragment. In addition, the sample injection efficiency was low (under $0.1 \%$ ); a lot of DNA molecules had been flushed to the waste in each assay.

We finally utilized this system for plasmid DNA sizing. The DNA was from E. coli (a transformant of BL21(DE3) competent cell), and it has a size of $4.46 \mathrm{kbp}$. Since the DNA has only one $\mathrm{XbaI}$ (a restriction enzyme) site, $\mathrm{XbaI}$ was used to digest the circular plasmid to a linear DNA. Figure 5A presents the BaNC-HDC results of a) plasmid DNA after $X b a I$ digestion, b) plasmid DNA before the digestion, and c) DNA size marker. Using the relationship between fragment size and relative BaNC-HDC mobility (the BaNC-HDC mobility of a DNA fragment is defined as the velocity of the fragment divided by the velocity of the eluent), ${ }^{[11 \mathrm{c}]}$ the linear DNA was estimated to be $4.5 \mathrm{kbp}$, very close to its theoretical value. Multiple peaks were observed in the middle trace, because of the coexistence of supercoiled and open circular DNA conformation. Multimers were also present in the extracted plasmid as reported. ${ }^{[14]}$ Figure 5B shows the separation results of the same samples using a slab-gel system. These two sets of data were comparable, but the operations of slab-gel separation were tedious and more than 100 ng DNA was utilized per assay, while the operations of BaNC-HDC separations were automated and less than 10 pg DNA was consumed per assay.

In conclusion, we have incorporated an EOP and a microchip injector with BaNC-HDC and constructed an integrated microfluidic system for gel-free DNA separations. With this incorporation, we can separate DNA molecules at high-speed and high-resolution reproducibly; relative standard deviations of peak areas for duplicated runs were normally around $5 \%$. The separation speed can be increased by either increasing the elution pressure (the voltage on the EOP) or by shortening the separation capillary. Under optimized conditions, the 1-kb plus DNA ladders can be routinely baseline-resolved in less than 10 min, and only a few DNA molecules were required for each assay. Importantly, the system generated virtually no waste (pLmin ${ }^{-1}$ effluent to waste), and the consumable costs were extremely low (the expenses amount to a few $\mathrm{nL}$ eluent and a few $\mathrm{pL}$ sample per assay). Furthermore, all operations of the system are automated. To realize the full benefit of this system, however, we need to improve the sample injection efficiency (the current injection efficiency was under $0.1 \%$ ). With the integration of the pump, injector, and column into a microchip device (all these components are readily integrated on a single chip), we believe the injection efficiency can be improved dramatically. We expect BaNC-HDC to be an excellent alternative technique to PFGE.

\section{Experimental Section}

\section{Preparation of EOP}

The EOP used in this work was recently developed in our lab, and it was assembled by stacking three basic pump units in series; each unit was composed of one +EOP and one EOP. See Supporting Information for details.

\section{Preparation of chip injector}

The injector consisted of a microfabricated cross channel inside a glass chip, and an off-chip six-port valve (Model 7725i, IDEX Corporation, Lake Forest, IL). The cross channels were round and had a diameter of approximately $170 \mu \mathrm{m}$, which were produced using standard photolithographic technologies following the process as described in the literature. ${ }^{[15]}$ Briefly, cross grooves were first created on two glass wafers. Because the cross pattern on a photomask had a line-width of $10 \mu \mathrm{m}$, the grooves were virtually semicircular after they were isotropicly etched to a depth of $85 \mu \mathrm{m}$. Round channels were formed as the two etched wafers were face-to-face aligned and bonded. Referring to Figure 1A, the separation 
capillary ( $70 \mathrm{~cm}$-long, $150 \mu \mathrm{m}$-o.d., and $2 \mu \mathrm{m}$-i.d.) was connected to the chip cross at position 1, and sample capillary, pump capillary, and auxiliary capillary (all $15 \mathrm{~cm}$-long, 150 $\mu \mathrm{m}$-o.d., and $15 \mu \mathrm{m}$-i.d.) were connected to the chip cross at positions 2,3 , and 4 , respectively. All capillaries were secured in positions using epoxy adhesive. The other ends of sample capillary and waste capillary were connected to the six-port valve. The two solid dots on the six-port valve indicates those ports were blocked. Figure S1c presents an image of the chip cross with four capillaries attached to it.

\section{Preparation of plasmid}

The E. coli (a transformant of BL21-(DE3) competent cell) was grown in $5 \mathrm{~mL}$ complete Luria-Bertani medium at $37^{\circ} \mathrm{C}$ overnight. Bacteria cells were harvested by centrifugation (13000 rpm for $1 \mathrm{~min}$ ). Plasmid was extracted from the cells using a commercial kit (Qiaprep spin miniprep kit, Qiagen, Germantown, MD). A restriction enzyme, Xbal (New England Biolabs, Ipswich, MA), was used to digest the plasmid; 10 activity units of $X b a$ al for $1.2 \mu \mathrm{g}$ plasmid DNA in a $20 \mu \mathrm{L}$ reaction. The digested plasmid was purified by a commercial kit (QIAquick PCR Purification Kit, Qiagen).

\section{Supplementary Material}

Refer to Web version on PubMed Central for supplementary material.

\section{References}

1. a) Danna K, Nathans D. Proc Natl Acad Sci USA. 1971; 68:2913-2917. [PubMed: 4332003] b) Kaplan DA, Russo R, Wilcox G. Anal Biochem. 1977; 78:235-243. [PubMed: 848745] c) Barron AE, Blanch HW. Sep Purif Methods. 1995; 24:1-118.

2. a) Schwartz DC, Cantor CR. Cell. 1984; 37:67-75. [PubMed: 6373014] b) Wagner L, Lai E. Electrophoresis. 1994; 15:1078-1083. [PubMed: 7859711]

3. a) Schmalzing D, Koutny L, Salas-Solano O, Adourian A, Matsudaira P, Ehrlich D. Electrophoresis. 1999; 20:3066-3077. [PubMed: 10596815] b) Carrilho E. Electrophoresis. 2000; 21:55-65. [PubMed: 10634470] c) Buchholz BA, Shi W, Barron AE. Electrophoresis. 2002; 23:1398-1409. [PubMed: 12116149]

4. Noolandi J. Electrophoresis. 1992; 13:394-395. [PubMed: 1505500]

5. Heller C, Slater GW, Mayer P, Dovichi N, Pinto D, Viovy JL, Drouin G. J Chromatogr A. 1998; 806:113-121.

6. a) Meagher RJ, Won JI, McCormick LC, Nedelcu S, Bertrand MM, Bertram JL, Drouin G, Barron AE, Slater GW. Electrophoresis. 2005; 26:331-350. [PubMed: 15657881] b) Lau HW, Archer LA. Phys Rev E. 2010; 81:031918.c) Albrecht JC, Lin JS, Barron AE. Anal Chem. 2011; 83:509-515. [PubMed: 21182303]

7. a) Zheng J, Yeung ES. Anal Chem. 2002; 74:4536-4547. [PubMed: 12236367] b) Zheng J, Yeung ES. Anal Chem. 2003; 75:3675-3680. [PubMed: 14572029]

8. Dickman MJ. J Chromatogr A. 2005; 1076:83-89. [PubMed: 15974072]

9. Han J, Turner SW, Craighead HG. Phys Rev Lett. 1999; 83:1688-1691.

10. Huang LR, Tegenfeldt JO, Kraeft JJ, Sturm JC, Austin RH, Cox EC. Nat Biotechnol. 2002; 20:1048-1051. [PubMed: 12219075]

11. a) Wang X, Wang S, Veerappan V, Byun CK, Nguyen H, Gendhar B, Allen RD, Liu S. Anal Chem. 2008; 80:5583-5589. [PubMed: 18500828] b) Wang X, Veerappan V, Cheng C, Jiang X, Allen RD, Dasgupta PK, Liu S. J Am Chem Soc. 2009; 131:40-41. [PubMed: 19072650] c) Wang X, Liu L, Pu Q, Zhu Z, Guo G, Zhong H, Liu S. J Am Chem Soc. 2012; 134:7400-7405. [PubMed: 22512501]

12. Small H. J Colloid Interface Sci. 1974; 48:147-161. 
13. a) He C, Lu JJ, Jia Z, Wang W, Wang X, Dasgupta PK, Liu S. Anal Chem. 2011; 83:2430-2433. [PubMed: 21375230] b) Gu C, Jia Z, Zhu Z, He C, Wang W, Morgan A, Lu JJ, Liu S. Anal Chem. 2012; 84:9609-9614. [PubMed: 23061696]

14. a) Potter H, Dressler D. Proc Natl Acad Sci USA. 1977; 74:4168-4172. [PubMed: 270661] b) Voss C, Schmidt T, Schleef M, Friehs K, Flaschel E. J Biotechnol. 2003; 105:205-213. [PubMed: 14580792]

15. a) Liu S, Elkin C, Kapur H. Electrophoresis. 2003; 24:3762-3768. [PubMed: 14613203] b) Liu S. Electrophoresis. 2003; 24:3755-3761. [PubMed: 14613202] 

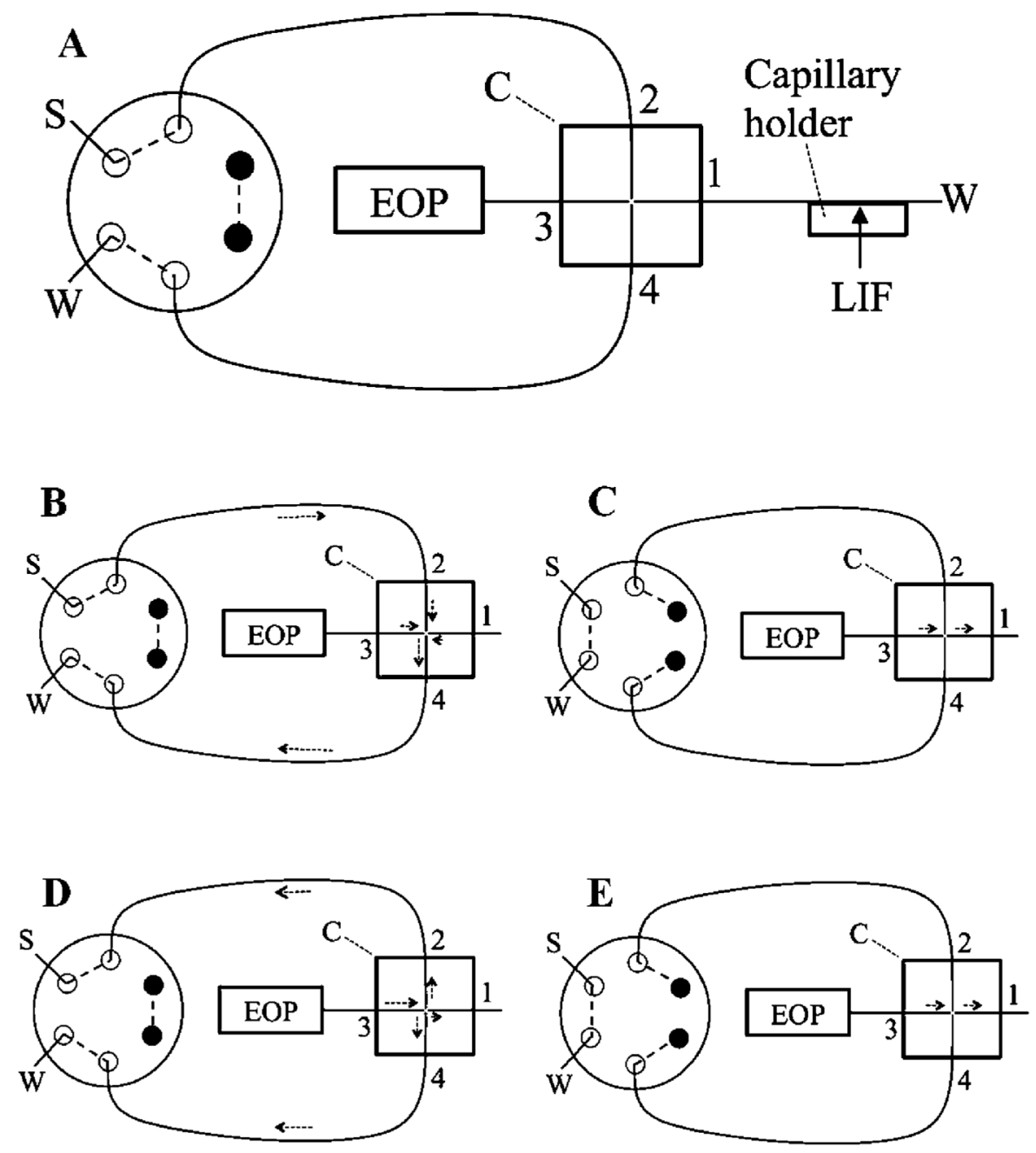

Figure 1.

Schematic diagram of experimental setup for BaNC-HDC. A) Experimental setup: $\mathrm{S}=$ sample, $\mathrm{W}=$ waste, and $\mathrm{C}=$ chip injector. The six-port injection valve is showing on the left. The solid dots indicate ports that are blocked. Capillaries connected to positions 1, 2, 3, and 4 on the chip injector are separation capillary, sample capillary, pump capillary, and waste capillary, respectively. The separation capillary has a length of from $40 \mathrm{~cm}$ to $70 \mathrm{~cm}$, an o.d. of $150 \mu \mathrm{m}$, and an i.d. of $2 \mu \mathrm{m}$, the other three capillaries had a length of $15 \mathrm{~cm}$, an o.d. of $150 \mu \mathrm{m}$, and an i.d. of $15 \mu \mathrm{m}$. B)-E) Schematic diagram depicting sample injection. The arrows indicate the flow directions (see text for details). 
A

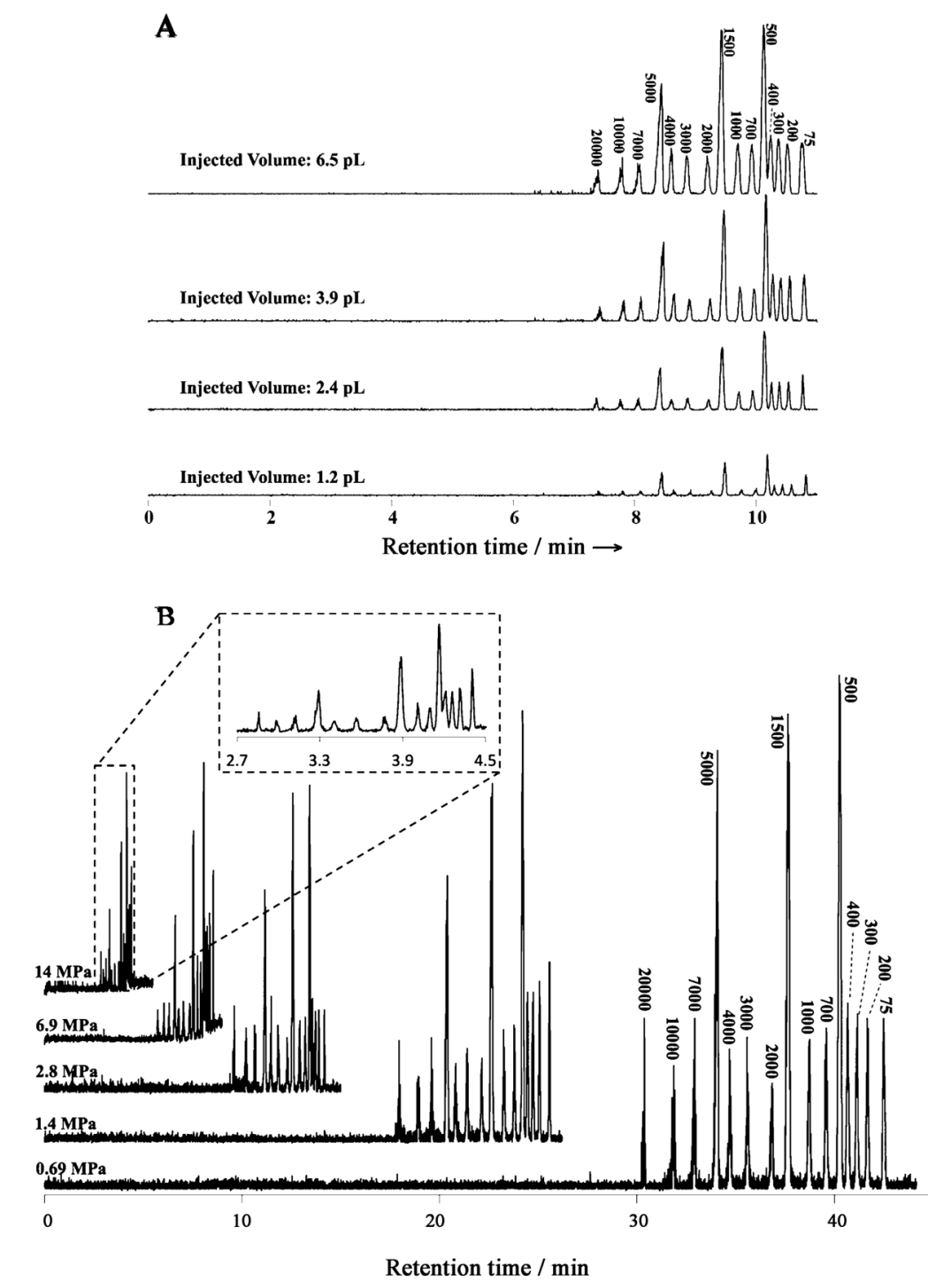

Figure 2.

Typical BaNC-HDC chromatograms under $\mathrm{pL} \mathrm{min}^{-1}$ flow rates and using $\mathrm{pL}$ samples. A) Chromatograms obtained at injected volumes from 1.2-6.5 pL. The separation capillary had a total length of $47.5 \mathrm{~cm}\left(42.5 \mathrm{~cm}\right.$ effective). The eluent was $5 \mathrm{mM} \mathrm{NH}_{4} \mathrm{Ac} / \mathrm{NH}_{4} \mathrm{OH}(\mathrm{pH}$ 8.0). The elution pressure was $2.1 \mathrm{MPa}$. The sample contained $15 \mathrm{DNA}$ fragments, and the total DNA concentration was $20 \mathrm{ng} \mu \mathrm{L}^{-1} ; 3.2 \mathrm{ng} \mu \mathrm{L}^{-1}$ for the $1.5 \mathrm{kbp}$ fragment, $3 \mathrm{ng} \mu \mathrm{L}^{-1}$ for the 0.5 and $5 \mathrm{kbp}$ fragments, $1 \mathrm{ng} \mu \mathrm{L}^{-1}$ for the $0.075,0.2,0.3,0.4,0.7$, and $1 \mathrm{kbp}$ fragments,

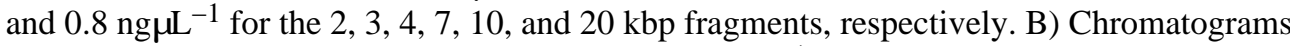
obtained at elution rates from approximately $40 \mathrm{pL} \mathrm{min}^{-1}$ (at $0.69 \mathrm{MPa}$ )-approximately 400 $\mathrm{pLmin}^{-1}$ (at $14 \mathrm{MPa}$ ). The separation capillary had an effective length of $65 \mathrm{~cm}$. The injection volume was estimated to be $2.4 \mathrm{pL}$, and the elution pressure was controlled by tuning the voltage $(550 \mathrm{~V}$ for $0.69 \mathrm{MPa}-11.1 \mathrm{kV}$ for $14 \mathrm{MPa}$ ) on the EOP. The inset shows an expanded view of the fast separation. All other experimental conditions were the same as in (A). 


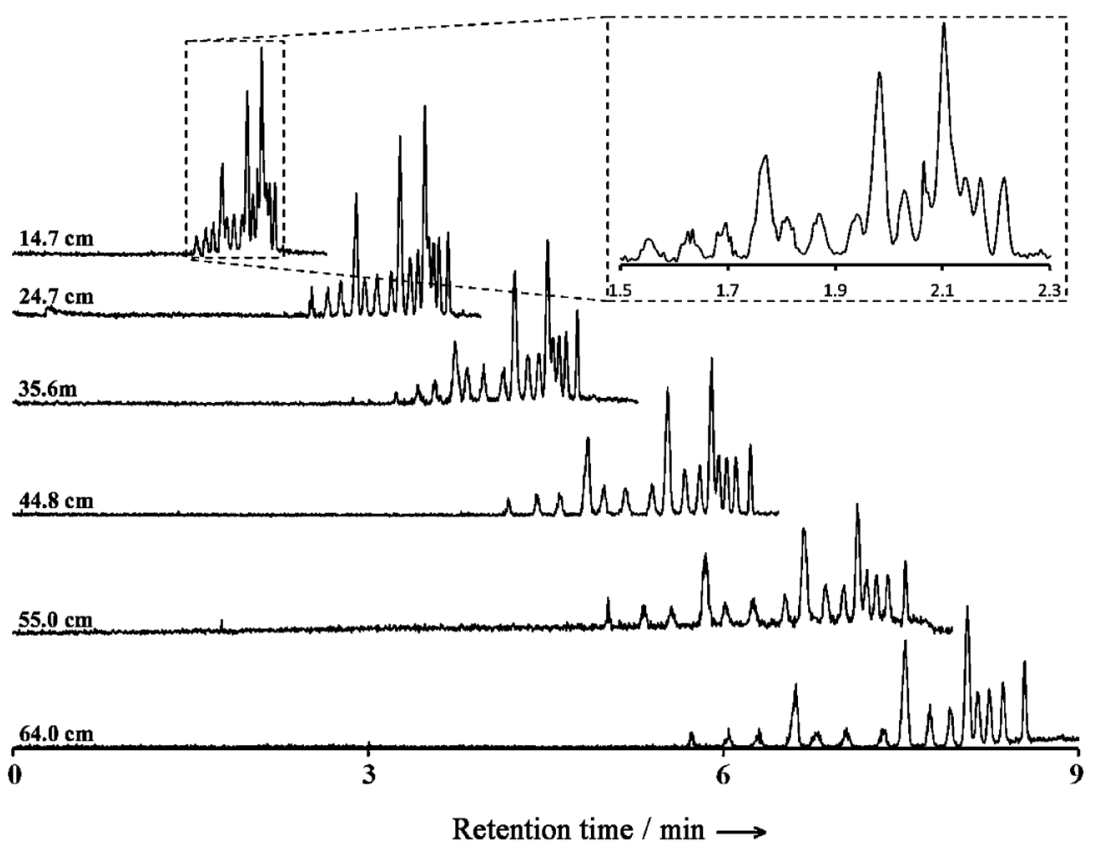

Figure 3.

Effect of effective capillary length on BaNC-HDC separation. The total capillary length was $69.4 \mathrm{~cm}$, and different effective lengths were obtained by generating windows at different positions of the separation capillary. The elution pressure was 6.9 MPa. The inset exhibits an expanded view of the fast separation. All other conditions were as in Figure 2B. 


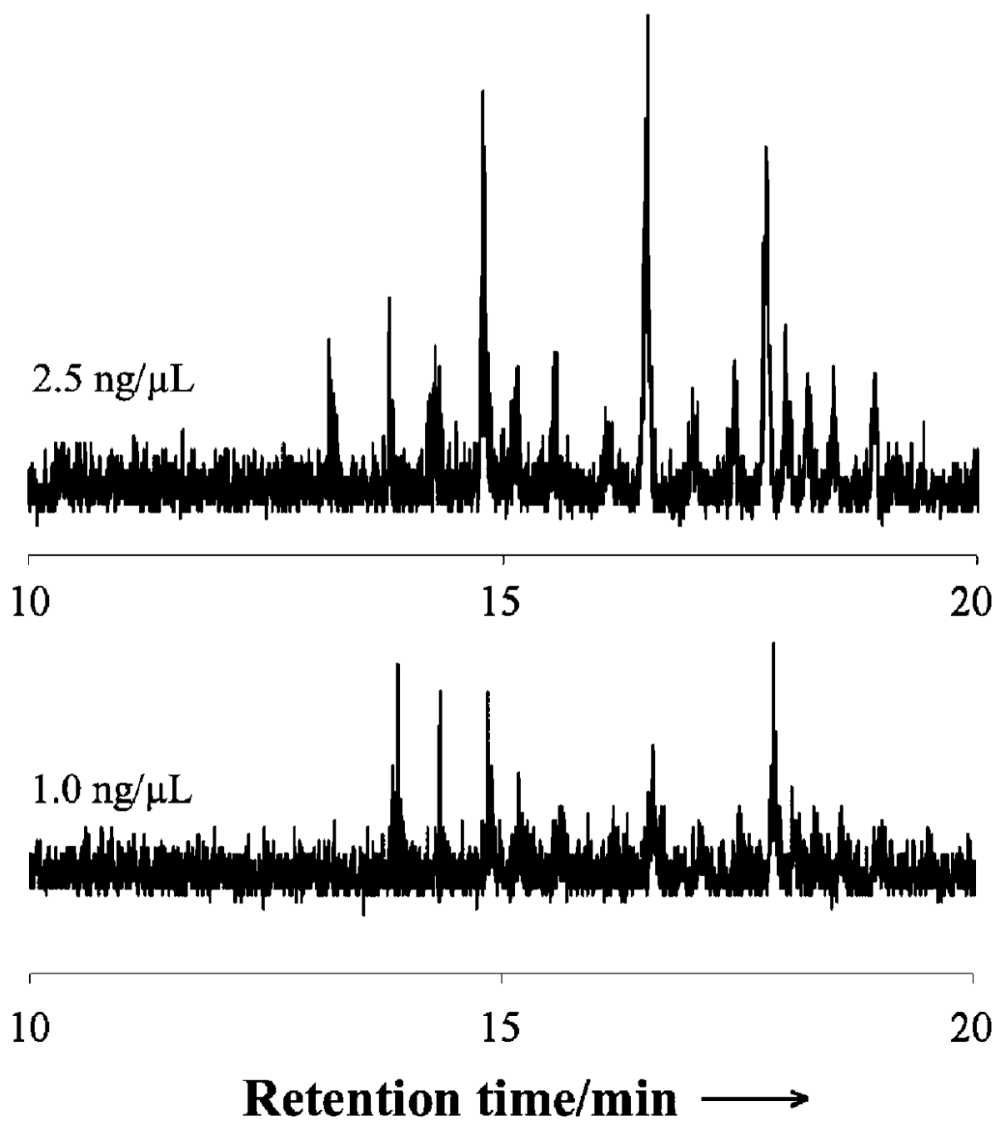

Figure 4.

DNA separation by BaNC-HDC at single-molecule level. The separation capillary had a total length of $40 \mathrm{~cm}$ length (35 cm effective). The injection volume was estimated to be 2.4 pL. The elution pressure was $0.69 \mathrm{MPa}$. The values above the chromatograms represent the total DNA concentration. All other conditions were as in Figure 2A. 


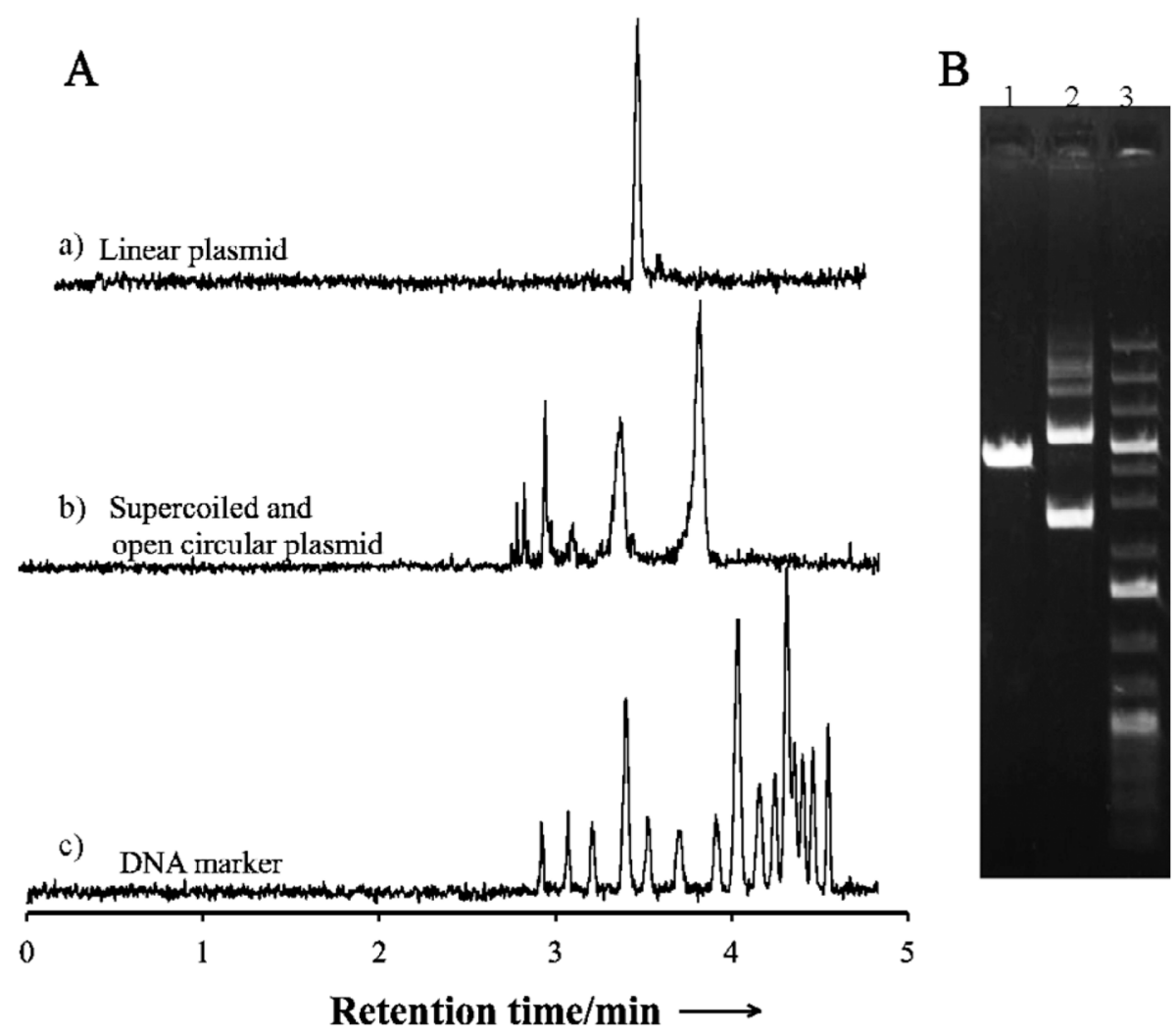

Figure 5.

BaNC-HDC analysis of plasmid DNA. A) Chromatograms of a) the linear plasmid DNA ( 3 ng $\mathrm{LL}^{-1}$ ) after $X b a$ I digestion, b) the supercoiled, open circular, and multimer DNA (7 $\mathrm{ng} \mu \mathrm{L}^{-1}$ in total) before the digestion, and c) DNA size marker (20 ng $\mathrm{L}^{-1}$ in total). The estimated injection volume was $2.4 \mathrm{pL}$, and the elution pressure was $13.8 \mathrm{MPa}$. All other conditions were as in Figure 2B. B) Agarose gel electrophoresis results for the samples, with Lane 1 corresponding to Trace a, Lane 2 corresponding to Trace b, and Lane 3 corresponding to Trace $\mathrm{c}$. The electrophoretic separation was performed using $\mathrm{Owl}^{*}$ EasyCast* B2 Mini Gel Electrophoresis Systems (Thermo Scientific, Waltham, MA) at 120 volts for $45 \mathrm{~min}$. The gel contained $0.7 \%$ agarose. $2 \mu \mathrm{L}$ of $60 \mathrm{ng} \mu \mathrm{L}^{-1}$ linear plasmid was loaded in Lane $1,1 \mu \mathrm{L}$ of $150 \mathrm{ng}^{-1} \mathrm{~L}^{-1}$ plasmid DNA before digestion was loaded in Lane 2, and $0.3 \mu \mathrm{L}$ of $500 \mathrm{ng} \mathrm{LL}^{-1}$ DNA size marker was loaded in Lane 3. 